\title{
Identification and antimicrobial susceptibility of methicillin-resistant Staphylococcus aureus-associated subclinical mastitis isolated from dairy cows in Bogor, Indonesia
}

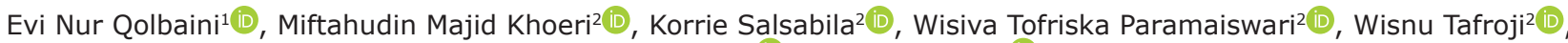 \\ I. Made Artika ${ }^{1,2}$ (i) and Dodi Safari² (i) \\ 1. Department of Biochemistry, IPB University, Jl. Raya Dramaga, Bogor, 16680, Indonesia; 2. Eijkman Institute for \\ Molecular Biology, Jl. Diponegoro No. 69 Jakarta, 10340, Indonesia. \\ Corresponding author: Dodi Safari, e-mail: safari@eijkman.go.id \\ Co-authors: ENQ: evinurqolbaini@yahoo.co.id, MMK: majid@eijkman.go.id, KS: korriesalsa@eijkman.go.id, \\ WTP: wisiva@eijkman.go.id, WT: wisnutafroji@eijkman.go.id, IMA: imart@eijkman.go.id \\ Received: 24-10-2020, Accepted: 30-03-2021, Published online: 13-05-2021
}

doi: www.doi.org/10.14202/vetworld.2021.1180-1184 How to cite this article: Qolbaini EN, Khoeri MM, Salsabila K, Paramaiswari WT, Tafroji W, Artika IM, Safari D (2021) Identification and antimicrobial susceptibility of methicillin-resistant Staphylococcus aureus-associated subclinical mastitis isolated from dairy cows in Bogor, Indonesia, Veterinary World, 14(5): 1180-1184.

\begin{abstract}
Background and Aim: Subclinical mastitis is an udder infection devoid of clinical symptoms, and Staphylococcus aureus is one of the bacteria causing this disease. This study aimed to identify and determine the prevalence and antibiotic susceptibility of methicillin-resistant $S$. aureus (MRSA)-associated subclinical mastitis isolated from dairy cows in Bogor, Indonesia.

Materials and Methods: $S$. aureus was isolated from subclinical mastitis milk specimens. All strains were confirmed by polymerase chain reaction-based detection of staphylococcal $n u c$, and MRSA was confirmed by the presence of $m e c A$. Antibiotic susceptibility was determined using the disk diffusion method.

Results: From 86 milk samples, 49 isolates (57\%) were confirmed as S. aureus. All S. aureus isolates were susceptible to tetracycline, gentamicin, chloramphenicol, erythromycin, and trimethoprim/sulfamethoxazole. Nine isolates were identified as MRSA $(10.5 \%)$.
\end{abstract}

Conclusion: In this study, we reported MRSA-associated subclinical mastitis in Bogor, Indonesia.

Keywords: Bogor, dairy cows, methicillin-resistant Staphylococcus aureus, subclinical mastitis.

\section{Introduction}

Globally, mastitis is an inflammation of the mammary gland, affecting dairy cows with high economic impact, including low milk production, increasing antibiotic residue contamination, and chronic infection, often leading to deaths $[1,2]$. It was reported that the prevalence of subclinical mastitis is higher than that of clinical mastitis [3]. Subclinical mastitis has a more common and serious impact on older lactating animals, contributing to most of the financial losses $[2,4]$. The major risk factors for developing mastitis include herd size, bedding material, and milking of mastitic cows [1,3]. Meanwhile, the age and number of parity (number of pregnancies carried by a cow) were significantly associated with the occurrence of subclinical mastitis [5]. At present, the diagnosis of subclinical mastitis is difficult and challenging to detect by visual inspection, and palpation of the udder than clinical mastitis due to the lack of

Copyright: Qolbaini, et al. Open Access. This article is distributed under the terms of the Creative Commons Attribution 4.0 International License (http://creativecommons.org/licenses/ by/4.0/), which permits unrestricted use, distribution, and reproduction in any medium, provided you give appropriate credit to the original author(s) and the source, provide a link to the Creative Commons license, and indicate if changes were made. The Creative Commons Public Domain Dedication waiver (http:// creativecommons.org/publicdomain/zero/1.0/) applies to the data made available in this article, unless otherwise stated. any overt manifestation, such as visible changes in the udder or milk [6,7]. At present, several tests are being used to define mastitis, including physicochemical and biological diagnostics, for example, $\mathrm{pH}$, electric conductivity, enzymes, biochemical molecules, and non-specific culture; somatic cell count; California mastitis test (CMT); digital mastitis detection tests; intramammary thermography; bio-sensors; and proteomic approaches[8].

Staphylococcus spp. (coagulase-negative) are the predominant contagious pathogens causing mastitis [3,9]. At present, Staphylococcus aureus infection of the mammary gland remains a major problem in the dairy industry worldwide [10]. TarazonaManrique et al. [11] reported that Streptococcus agalactiae and $S$. aureus were the most prevalent bacterial pathogens causing mastitis in specialized dairy herds in the Highlands of Boyacá, Colombia. It was also reported that Staphylococcus species were the dominant bacteria isolated from mastitis and subclinical mastitis cases in Ethiopia [1,5]. In Rwanda, among 123 crossbreed milking cows from 13 dairy farms, the prevalence of subclinical mastitis was mostly $(50.4 \%)$ caused by the pathogens, coagulase-negative Staphylococcus (CNS), and $S$. aureus [4]. In Kenya, it was reported that the predominant bacteria from cow milk samples 
with clinical and subclinical mastitis were CNS followed by Streptococcus species, S. aureus, Pseudomonas aeruginosa, and Enterobacter species [3]. Methicillin-resistant S. aureus (MRSA) is a drug-resistant bacterial pathogen responsible for various infections worldwide, from humans to animals. MRSA strains have been detected in animals and are a frequent colonizer of animals, especially livestock, as new reservoirs. Livestock-associated MRSA (LA MRSA) causes infection in economically important livestock [12]. It was reported that $12.2 \%$ of mastitis cases were infected with MRSA isolated from milk samples obtained from the quarters [13]. For example, in Egypt, $35.7 \%$ of $S$. aureus strains isolated from milk samples of buffaloes and dairy cattle were cefoxitin resistant, and polymerase chain reaction (PCR) for mecA and coa genes revealed MRSA [14].

Recently, Ramandinianto et al. [15] reported that two MRSA strains were isolated from 150 cow milk samples from three village dairy farms in East Java, Indonesia. This study aimed to identify and determine the prevalence and antibiotic susceptibility of MRSAassociated subclinical mastitis isolated from dairy cows in Bogor, Indonesia.

\section{Materials and Methods}

\section{Ethical approval}

Ethical approval was not required for this study; however, samples were collected as per standard sample collection procedure.

\section{Study period and location}

Milk samples were collected in 2013 and 2014 from cows with subclinical mastitis in a dairy cow farm in Bogor, Indonesia, as previously described [16].

\section{Milk sample collection}

CMT-positive specimens (86/102) were used in this study [16]. One standard loop $(0.01 \mathrm{~mL})$ of the milk sample was streaked onto $5 \%$ sheep blood agar using the quadrant-streaking method for each sample. The plates were incubated aerobically at $37^{\circ} \mathrm{C}$ for 24-48 h. After incubation, colonies were identified according to their Gram reaction, cellular morphology, and catalase test [16]. The presumptive $S$. aureus isolates were stored at $-80^{\circ} \mathrm{C}$ in a skim milk tryptone glucose glycerol medium [16].

\section{Molecular identification of $\boldsymbol{S}$. aureus and MRSA}

All isolates were subcultured on a blood agar plate $(5 \%)$ and incubated at $37^{\circ} \mathrm{C}$ for $18-24 \mathrm{~h}$. DNA was extracted using the heat shock method as previously described [17]. The harvested bacteria were placed into a $300 \mu \mathrm{L}$ TE buffer, heated to $100^{\circ} \mathrm{C}$ for $5 \mathrm{~min}$, and frozen at $-20^{\circ} \mathrm{C}$ for $10 \mathrm{~min}$. Then, they were centrifuged at $13,000 \times g$ for $10 \mathrm{~min}$. The pellet and the supernatant were separated and stored at $-30^{\circ} \mathrm{C}$. All phenotypically identified isolates were confirmed using specific PCR that targeted the thermonuclease (nuc) gene with a forward primer (5'-TCAGCAAATGCATCACAAACAG-3') and a reverse primer (5'-CGTAAATG CACTTGCTTCAGG-3'). Using PCR, the isolates resistant to cefoxitin or oxacillin were tested for the detection of the mecA gene. Specific primers for the mecA gene used reverse (5'-AACGATTGTGACACGATAGCC-3') and forward (5'-GGGATCATAGCGTCATTATTC-3') primers. For each reaction, a master mix $(25 \mu \mathrm{L})$ containing GoTaq Green Master Mix (Promega, Madison, WI, USA), $25 \mu \mathrm{M}$ primers $0.5 \mu \mathrm{L}$ for each primer, nuclease-free water, and $2.5 \mu \mathrm{L}$ DNA template was prepared. Conventional PCR was performed to detect the $m e c A$ gene under the following conditions: $5 \mathrm{~min}$ at $94^{\circ} \mathrm{C}$; followed by 35 cycles of denaturation at $94^{\circ} \mathrm{C}$ for $30 \mathrm{~s}$, annealing at $55^{\circ} \mathrm{C}$ for $30 \mathrm{~s}$ and extension at $72^{\circ} \mathrm{C}$ for $1 \mathrm{~min}$, and a final extension at $72^{\circ} \mathrm{C}$ for 10 $\min [18,19]$.

\section{Antimicrobial susceptibility test}

All $S$. aureus isolates were tested for antibiotic susceptibility using the disk diffusion method on Mueller-Hinton agar, according to the Clinical Laboratory Standards Institute (CLSI) 2019. The antimicrobial disks (Oxoid) contained the following: Chloramphenicol $(30 \mu \mathrm{g})$, cefoxitin $(30 \mu \mathrm{g})$, erythromycin $(15 \mu \mathrm{g})$, sulfamethoxazole/trimethoprim $(23.75 / 1.25 \mu \mathrm{g})$, gentamicin $(10 \mu \mathrm{g})$, oxacillin $(1 \mu \mathrm{g})$, and tetracycline $(30 \mu \mathrm{g})$. Isolates resistant to cefoxitin and positive for the mecA gene were reported as MRSA, according to CLSI [20].

\section{Results}

In this study, 73 presumptive $S$. aureus strains were isolated and identified from 86 milk samples with subclinical mastitis $(84.5 \%)$. All strains were confirmed by PCR amplification of staphylococcal nuc (the PCR fragment length was $225 \mathrm{bp}$ ) and mecA genes (the PCR fragment length was $527 \mathrm{bp}$ ), resulting in $57.0 \%$ positivity for the nuc gene $(49 / 86)$ and $10.5 \%$ positivity for $n u c+m e c A$ genes $(9 / 86$; MRSA) (Table-1).

We used the disk diffusion method for the antibiogram. We found that all $S$. aureus strains were susceptible to tetracycline, gentamicin, chloramphenicol, erythromycin, and trimethoprim-sulfamethoxazole (Table-2). Meanwhile, $81.6 \%$ of the strains were susceptible to cefoxitin and oxacillin (Table-2). We found that all nine MRSA strains were non-susceptible to oxacillin and cefoxitin antibiotics. Here, the prevalence of MRSA among milk specimens with subclinical mastitis was $10.5 \%(9 / 86)$.

\section{Discussion}

MRSA is currently a global concern and has been reported as a major cause of health care-, community-, and livestock-associated infections [21,22]. MRSA has become an emerging and growing concern in companion and food-producing animals [23]. Our study found that $10.5 \%$ of MRSA strains were isolated and identified from milk specimens with 
Table_1: Identification of $S$. aureus and MRSA strains collected from 86 milk samples associated with subclinical mastitis from a dairy cow farm, Bogor, Indonesia.

\begin{tabular}{lc}
\hline S. aureus and MRSA identification & n (\%) \\
\hline Presumptive isolate & $73(84.9)$ \\
PCR positive for nuc gene & $49(57.0)$ \\
PCR positive for nuc and mecA genes (MRSA) & $9(10.5)$ \\
\hline
\end{tabular}

MRSA = Methicillin-resistant $S$. aureus, $S$. aureus=

Staphylococcus aureus, PCR=Polymerase chain reaction

Table-2: Antibiogram profiles 49 Staphylococcus aureus strains collected from milk samples associated with subclinical mastitis from a dairy cow farm, Bogor, Indonesia.

\begin{tabular}{lc}
\hline Antimicrobial agent & $\begin{array}{c}\text { Number (\%) of } \\
\text { susceptible strains }\end{array}$ \\
\hline Gentamicin & $49(100)$ \\
Tetracycline & $49(100)$ \\
Erythromycin & $49(100)$ \\
Trimethoprim/sulfamethoxazole & $49(100)$ \\
Chloramphenicol & $49(100)$ \\
Cefoxitin & $40(81.6)$ \\
Oxacillin & $40(81.6)$ \\
\hline
\end{tabular}

subclinical mastitis from a dairy farm in Bogor, Indonesia. This finding agrees with the previous study of Guimarães et al. [13], who reported that $12.2 \%$ of MRSA was isolated from milk samples in São Paulo, Brazil. Recently, it was reported that the prevalence of $S$. aureus with PCR-positive mecA (MRSA) was $17.89 \%$ among milk and nasal swab samples from dairy cattle in Malaysia [24]. However, a lower rate (2\%) of LA MRSA was observed from raw goat milk samples from the same country, Malaysia [25]. In Bangladesh, the prevalence of MRSA was $8.96 \%$ in clinical caprine mastitis cases [26].

Surveillance of MRSA prevalence causing mastitis and subclinical mastitis is important for the animals' health because $\beta$-lactam drugs are still the most common antimicrobials used to treat mastitis, because alternative treatment with non- $\beta$-lactam antibiotics is limited [13,27]. Misuse and frequent use of antibiotics for prophylaxis or in animal feed to enhance growth play a crucial role in the emergence and spread of MRSA [28]. A majority of MRSA strains were more resistant to multiple antibiotics among $S$. aureus isolates recovered from bovine mastitis cases in Shanghai and Zhejiang areas of China [29]. In Bangladesh, multidrug-resistant $S$. aureus isolates from bovine mastitis milk samples were tetracycline, novobiocin, methicillin, vancomycin, and cephradine resistant [30]. Here, we found all MRSA strains with the mecA gene confirmed by the PCR method to be non-susceptible to oxacillin and cefoxitin. The presence of the mecA gene was also identified among oxacillin-susceptible $S$. aureus isolates [13].

\section{Limitation of the study}

Our study was limited to only collecting milk samples from a dairy cow. In this study, we did not collect nasal swab samples from dairy workers. MRSA could be transmitted from animals, including dogs, cats, horses, small exotic animals, wildlife animals, and livestock, as a reservoir to humans, and vice versa [31,32]. The MRSA strains might be transmitted to humans by close contact and handling of dairy cows, as the same clonal complex of MRSA isolated from cow and dairy farmworkers was found [33]. MRSA is the most prevalent bacterium in conventional dairy farms, followed by organic, small, and large farms, in this order, and was correlated with lack of hygiene during milking [27]. The common route of MRSA transmission is through workers' hands, udder cloths, and milking equipment, such as teat liners [27]. Good hygiene practices during milking, milk production, or animal handling; good husbandry; and biosecurity measures can reduce the risk of MRSA transmission in an animal population $[21,27]$.

\section{Conclusion}

Good hygiene practices during milking, milk production, or animal handling should be used to reduce the risk of MRSA transmission within a dairy farm. In summary, our study discovered $57 \%$ and $10.5 \%$ of S. aureus and MRSA, respectively, isolated from raw milk of subclinical mastitis dairy cows. This study demonstrated that antibiotics could be used to treat MRSA-associated subclinical mastitis in dairy cows.

\section{Authors' Contributions}

ENQ: Conception, design, analysis, and interpretation of data. MMK: Acquisition of data, and analysis and interpretation of data. KS: Acquisition of data, and analysis and drafted the manuscript. WTP: Acquisition of data, and analysis and interpretation of data. WT: Acquisition of data and revised the manuscript critically. IMA: Conception, design, and revised the manuscript critically. DS: Conception, design, interpretation of data, and drafted the manuscript. All authors have read and approved the final manuscript.

\section{Acknowledgments}

The authors highly appreciate all the farmers from Kawasan Usaha Peternakan (KUNAK) cow dairy farm in Cibungbulang, Bogor, Indonesia, for their participation. This study was funded by Ministry of Research and Technology, Republic of Indonesia/ National Research and Innovation Agency.

\section{Competing Interests}

The authors declare that they have no competing interests.

\section{Publisher's Note}

Veterinary World remains neutral with regard to jurisdictional claims in published institutional affiliation. 


\section{References}

1. Abebe, R., Hatiya, H., Abera, M., Megersa, B. and Asmare, K. (2016) Bovine mastitis: Prevalence, risk factors and isolation of Staphylococcus aureus in dairy herds at Hawassa milk shed, South Ethiopia. BMC Vet. Res., 12(1): 270.

2. Romero, J., Benavides, E. and Meza, C. (2018) Assessing financial impacts of subclinical mastitis on Colombian dairy farms. Front. Vet. Sci., 5: 273.

3. Mbindyo, C.M., Gitao, G.C. and Mulei, C.M. (2020) Prevalence, etiology, and risk factors of mastitis in dairy cattle in Embu and Kajiado Counties, Kenya. Vet. Med. Int., 2020: 8831172 .

4. Mpatswenumugabo, J.P., Bebora, L.C., Gitao, G.C., Mobegi, V.A., Iraguha, B., Kamana, O. and Shumbusho, B. (2017) Prevalence of Subclinical Mastitis and Distribution of Pathogens in Dairy Farms of Rubavu and Nyabihu Districts, Rwanda. J. Vet. Med., 2017: 8456713.

5. Birhanu, M., Leta, S., Mamo, G. and Tesfaye, S. (2017) Prevalence of bovine subclinical mastitis and isolation of its major causes in Bishoftu Town, Ethiopia. BMC Res. Notes, 10(1): 767.

6. Salvador, R.T., Beltran, J.M.C., Abes, N.S., Gutierrez, C.A. and Mingala, C.N. (2012) Short communication: Prevalence and risk factors of subclinical mastitis as determined by the California mastitis test in water buffaloes (Bubalus bubalis) in Nueva Ecija, Philippines. J. Dairy Sci., 95(3): 1363-1366.

7. Hussein, H.A., El-Razik K.A.E., Gomaa, A.M., Elbayoumy, M.K., Abdelrahman, K.A. and Hosein, H.I. (2018) Milk amyloid A as a biomarker for diagnosis of subclinical mastitis in cattle. Vet. World, 11(1): 34-41.

8. Chakraborty, S., Dhama, K., Tiwari, R., Yatoo, M.I., Khurana, S.K., Khandia, R., Munjal, A., Munuswamy, P., Kumar, M.A., Singh, M., Singh, R., Gupta, V.K., Chaicumpa, W. (2019) Technological interventions and advances in the diagnosis of intramammary infections in animals with emphasis on bovine population - A review. Vet. Q., 39:76.

9. Dufour, S., Labrie, J. and Jacques, M. (2019) The mastitis pathogens culture collection. Microbiol. Resour. Announc., 8(15): e00133-19.

10. Rainard, P., Foucras, G., Fitzgerald, J.R., Watts, J.L., Koop, G. and Middleton, J.R. (2018) Knowledge gaps and research priorities in Staphylococcus aureus mastitis control. Transbound. Emerg. Dis., 65(Suppl 1): 149-165.

11. Tarazona-Manrique, L.E., Villate-Hernández, J.R. and Andrade-Becerra, R.J. (2019) Bacterial and fungal infectious etiology causing mastitis in dairy cows in the highlands of Boyacá (Colombia). Rev. Fac. Med. Vet. Zootec., 66(3): 208-218.

12. Chuang, Y.Y. and Huang, Y.C. (2015) Livestock-associated meticillin-resistant Staphylococcus aureus in Asia: An emerging issue? Int. J. Antimicrob. Agents, 45(4): 334-340.

13. Guimarães, F.F., Manzi, M.P., Joaquim, S.F., RichiniPereira, V.B. and Langoni, H. (2017) Short communication: Outbreak of methicillin-resistant Staphylococcus aureus (MRSA)-associated mastitis in a closed dairy herd. J. Dairy Sci., 100(1): 726-730.

14. Algammal, A.M., Enany, M.E., El-Tarabili, R.M., Ghobashy, M.O.I. and Helmy, Y.A. (2020) Prevalence, antimicrobial resistance profiles, virulence and enterotoxins-determinant genes of MRSA isolated from subclinical bovine mastitis in Egypt. Pathogens, 9(5): 362.

15. Ramandinianto, S.C., Khairullah, A.R. and Effendi, M.H. (2020) MecA gene and methicillin-resistant Staphylococcus aureus (MRSA) isolated from dairy farms in East Java, Indonesia. Biodivers. J. Biol. Divers., 21(8): 3562-3568.

16. Qolbaini, E.N., Artika, I.M. and Safari, D. (2014) Detection of subclinical mastitis in dairy cows using California mastitis test and udder pathogen. Curr. Biochem., 1(2): 66-70.

17. Pai, R., Gertz, R.E. and Beall, B. (2006) Sequential multiplex PCR approach for determining capsular serotypes of Streptococcus pneumoniae isolates. J. Clin. Microbiol., 44(1): 124-131.

18. Suryatenggara, A.N., Khoeri, M.M., Waslia, L., Tafroji, W., Kumalawati, J., Subekti, D., Adiwinata, R., Waslia, L. and Loho, T. (2013) Identification and antibiotic susceptibility of methicillin-resistant Staphylococcus aureus strains collected at a referral hospital, Jakarta, Indonesia in 2013. Southeast Asian J. Trop. Med. Public Health, 49(6): 7.

19. Nelwan, E.J., Sinto, R., Subekti, D., Adiwinata, R., Waslia, L., Loho, T., Safari, D. and Widodo, D. (2018) Screening of methicillin-resistant Staphylococcus aureus nasal colonization among elective surgery patients in a referral hospital in Indonesia. BMC Res. Notes, 11(1): 56.

20. Weinstein, M.P. (2019) Performance Standards for Antimicrobial Susceptibility Testing. Clinical and Laboratory Standards Institute, Pennsylvania, PA.

21. Gopal, S. and Divya, K.C. (2017) Can methicillin-resistant Staphylococcus aureus prevalence from dairy cows in India act as a potential risk for community-associated infections? A review. Vet. World., 10(3): 311-318.

22. Haran, K.P., Godden, S.M., Boxrud, D., Jawahir, S., Bender, J.B. and Sreevatsan, S. (2012) Prevalence and characterization of Staphylococcus aureus, including methicillin-resistant Staphylococcus aureus, isolated from bulk tank milk from Minnesota dairy farms. J. Clin. Microbiol., 50(3): 688-695.

23. Chon, J., Sung, K. and Khan, S. (2017) MethicillinResistant Staphylococcus aureus (MRSA) in FoodProducing and Companion Animals and Food Products. In: Frontiers in Staphylococcus aureus. IntechOpen, London. Available from: https://www.intechopen.com/ books/frontiers-in-i-staphylococcus-aureus-i-/methicillin-resistant-staphylococcus-aureus-mrsa-in-food-producing-and-companion-animals-and-food-pr. Retrieved on 09-11-2020.

24. Aklilu, E. and Chia, H.Y. (2020) First mecC and mecA positive livestock-associated methicillin-resistant Staphylococcus aureus (mecC MRSA/LA-MRSA) from dairy cattle in Malaysia. Microorganisms, 8(2): 147.

25. Chai, M.H., Faiq, T.A.M., Ariffin, S.M.Z., Suhaili, Z., Sukiman, M.Z. and Ghazali, M.F. (2020) Prevalence of methicillin-resistant Staphylococcus aureus in raw goat milks from selected farms in Terengganu, Malaysia. Trop. Anim. Sci. J., 43(1): 64-69.

26. Rana, E.A., Das, T., Dutta, A., Rahman, M., Bostami, M.B., Akter, N. and Barua, H. (2020) Coagulase-positive methicillin-resistant Staphylococcus aureus circulating in clinical mastitic goats in Bangladesh. Vet. World, 13(7): 1303-1310.

27. Schnitt, A. and Tenhagen, B.A. (2020) Risk factors for the occurrence of methicillin-resistant Staphylococcus aureus in dairy herds: An update. Foodborne Pathog. Dis., 17(10): 585-596.

28. Van, T.T.H., Yidana, Z., Smooker, P.M. and Coloe, P.J. (2020) Antibiotic use in food animals worldwide, with a focus on Africa: Pluses and minuses. J. Glob. Antimicrob. Resist., 20: 170-177.

29. Li, T., Lu, H., Wang, X., Gao, Q., Dai, Y., Shang, J. and Li, M. (2017) Molecular characteristics of Staphylococcus aureus causing bovine mastitis between 2014 and 2015. Front Cell Infect. Microbiol., 7: 127.

30. Salauddin, M., Akter, M.R., Hossain, M.K., Nazir, K.H.M., Noreddin, A. and El Zowalaty, M.E. (2020) Molecular detection of multidrug-resistant Staphylococcus aureus isolated from bovine mastitis milk in Bangladesh. Vet. Sci., 7(2): 36 .

31. Schaumburg, F., Pauly, M., Anoh, E., Mossoun, A., Wiersma, L., Schubert, G., Flammen, A., Alabi, A.S., Muyembe-Tamfum, J.J., Grobusch, M.P., Karhemere, S., Akoua-Koffi, C., Couacy-Hymann, E., Kremsner, P.G., Mellmann, A., Becker, K., Leendertz, F.H. and Peters, G. (2015) Staphylococcus aureus complex from animals and 
humans in three remote African regions. Clin. Microbiol. Infect., 21(4): 345.e1-345.e8.

32. Petinaki, E. and Spiliopoulou, I. (2015) Methicillin-resistant Staphylococcus aureus colonization and infection risks from companion animals: Current perspectives. Vet. Med. Res. Rep., 6: 373-382.
33. Locatelli, C., Cremonesi, P., Caprioli, A., Carfora, V., Ianzano, A., Barberio, A., Morandi, S., Casula, A., Castiglioni, B., Bronzo, V. and Moroni, P. (2017) Occurrence of methicillin-resistant Staphylococcus aureus in dairy cattle herds, related swine farms, and humans in contact with herds. J. Dairy Sci., 100(1): 608-619.

$* * * * * * * *$ 